\title{
Effects of selective serotonin reuptake inhibitors on motor neuron survival
}

This article was published in the following Dove Press journal:

International Journal of General Medicine

26 May 2009

Number of times this article has been viewed

\author{
Lily B Anderson' \\ Phaedra B Anderson' \\ Thea B Anderson' \\ Amy Bishop ${ }^{2}$ \\ James Anderson ${ }^{2}$ \\ 'Cherokee Labsystems, Huntsville, \\ AL USA; ${ }^{2}$ Department of Biology, \\ University of Alabama in Huntsville, \\ Huntsville, AL, USA
}

Correspondence: Amy Bishop

Department of Biology, University of Alabama in Huntsville, Huntsville, AL

35899, USA

Tel $+|256824646|$

Fax +I 2568246305

Email bishopa@uah.edu

\begin{abstract}
Selective serotonin reuptake inhibitors (SSRIs) such as fluoxetine and paroxetine are prescribed to relieve clinical depression and a variety of other disorders. Recently tardive dyskinesia, as well as other movement disorders, have been found to be a clinical side effect of SSRIs. In light of these emerging side effects, we asked if motor neurons were affected by SSRI. Motor neurons were challenged with fluoxetine and paroxetine at clinically relevant doses as well as at lesser and greater doses. Ethanol was used as a negative control and another group of cells was left untreated. As expected, in alcohol-treated cells, there was significant decrease in cell survival and neurite outgrowth. In untreated cells there was no effect in either cell survival or neurite outgrowth. In fluoxetine-treated motor neurons there was $\sim 52 \%$ cell death while in paroxetine-treated cells there was $14 \%$ cell survival and both SSRIs caused significant loss of the percentage of neurite-bearing cells. Both SSRIs decreased cell survival in a dose-dependent manner. This study is provocative enough to call for further in vivo studies.
\end{abstract}

Keywords: fluoxetine, paroxetine, motor neurons, NSC34, neurotoxicity, SSRI

\section{Background}

Selective serotonin reuptake inhibitors (SSRIs) are prescribed for disorders such as clinical depression and more recently for obsessive-compulsive disorder (OCD), premenstrual dysphoric disorder (PMDD), eating disorders, social anxiety, and panic disorders. SSRIs are also approved for the treatment of major depressive disorder and OCD in pediatric patients, both preadolescent and adolescent. ${ }^{1}$ The two most prescribed SSRIs are fluoxetine hydrochloride and paroxetine hydrochloride. ${ }^{2}$ Fluoxetine hydrochloride is the most widely prescribed antidepressant medication in history. Since its introduction it has been prescribed to over 54 million patients worldwide. ${ }^{2}$

The mechanisms of action of SSRIs are presumed to be linked to its inhibition of central nervous system (CNS) neuronal uptake of serotonin. Studies at clinically relevant doses have demonstrated that fluoxetine and paroxetine block the uptake of serotonin in human platelets, rodent neurons, and other systems. ${ }^{1,2}$ However, the mechanism of action has not been fully elucidated and there may be other processes at work. Recently, a variety of side effects of SSRI therapy have come to light, specifically muscle twitches and tardive dyskinesia, all indicative of neuron damage. In one key study it was found that SSRIs affect development of the projection of thalamocortical fibers which has implications for development of afferent (sensory) pathways. ${ }^{3}$ Another key study found that SSRIs induced cell death in a hippocampal cell line and PC12 cell line, although the mechanism of neurotoxicity is still unknown which has implications for both the CNS and peripheral nervous system (PNS). ${ }^{4}$ 
In light of the emerging side effects that implicate motor neuron damage, and in light of possible neurotoxicity of SSRIs, we asked what, if any, are the effects of SSRIs on motor neurons at clinically relevant serum concentrations. Here we challenge motor neurons with the two most common SSRIs and assay cell survival and neurite outgrowth.

\section{Methods}

\section{Growth and maintenance of NSC34 cells}

Growth and maintenance of the NSC34 cells was performed as described. ${ }^{5,7} \mathrm{NSC} 34$ cells were made from a fusion of primary mouse spinal cord motor neurons with spinal neuroblastoma cells which have many of the characteristics of motor neurons assayed for thus far and are an accepted model of motor neurons. ${ }^{5,7-9}$ The cells were grown in a humidified $5 \% \mathrm{CO}_{2}$ environment in plastic T25 flasks in Dulbecco's modified Eagle's medium (Mediatech, Logan, UT, USA) without sodium pyruvate and supplemented with $10 \%$ heat-inactivated fetal bovine serum..$^{5,7}$

\section{Assay of cell survival}

The percentage of cell survival was assayed by the percentage of healthy cells remaining after treatment. Healthy cells were defined as those bearing neurites and those that excluded Trypan blue..$^{5-7}$ Any cells that detached from the plate were also assayed and $\sim 100 \%$ were found to no longer exclude Trypan blue. ${ }^{5,7}$

\section{Source and description of Prozac}

Fluoxetine hydrochloride (( \pm$)-\mathrm{N}$-methyl-3-phenyl-3$[(\alpha, \alpha, \alpha$-trifluoro- $p$ tolyl)oxy]propylamine hydrochloride $)$ with the empirical formula of $\mathrm{C}_{17} \mathrm{H}_{18} \mathrm{~F}_{3} \mathrm{NO} \cdot \mathrm{HCl}$ was used. Fluoxetine hydrochloride is a white to off-white crystalline solid with a solubility of $4 \mathrm{mg} / \mathrm{mL}$ in water or DMSO. Each capsule (pulvule) contains fluoxetine hydrochloride equivalent to $10 \mathrm{mg}(32.3 \mu \mathrm{mol}), 20 \mathrm{mg}(64.7 \mu \mathrm{mol})$, or $40 \mathrm{mg}(129.3 \mu \mathrm{mol})$ of fluoxetine along with a variety of inert ingredients and occupants. We used pure fluoxetine (Sigma catalogue F132; Sigma Aldrich, St. Louis, MO, USA).

\section{Treatment of cells with fluoxetine}

We dissolved fluoxetine in DMEM tissue culture media at a concentration of $15 \mathrm{ng} / \mathrm{ml}$ which is comparable to the serum concentrations found in a 12-year-old patient undergoing SSRI therapy with fluoxetine. ${ }^{1}$

\section{Source and description of paxil}

Paroxetine hydrochloride ((-)-trans-4R-(4'-fluorophenyl)3S-[(3',4'-methylenedioxyphenoxy) methyl] piperidine hydrochloride hemihydrate) with the empirical formula of $\mathrm{C}_{19} \mathrm{H}_{20} \mathrm{FNO}_{3} \cdot \mathrm{HCl} \bullet 1 / 2 \mathrm{H}_{2} \mathrm{O}$ was used. Paroxetine hydrochloride is an odorless, off-white powder, having a melting point range of $120^{\circ} \mathrm{C}$ to $138^{\circ} \mathrm{C}$ and a solubility of $5.4 \mathrm{mg} / \mathrm{mL}$ in water. We used pure paroxetine from Sigma.

\section{Addition of paroxetine to cells}

Paroxetine was dissolved in DMEM tissue culture media at the concentration of $31 \mathrm{ng} / \mathrm{ml}$ which is comporable to the serum conetrations found in a 12-year-old patient undergoing SSRI therapy. ${ }^{1}$

\section{Addition of control agents}

Alcohol (USP grade 100\% ethanol) was administered at the "legally drunk" blood alcohol level of $0.08 \%$. Untreated cells were left in their own media and vehicle controls were added.

\section{Cell survival and percentage of neurite outgrowth}

Cells were assessed 24 hours post-treatment, photographed, and cell death was assayed by Trypan blue exclusion. Neurons that are dead round up and either remain adhered or float away. We have found that $100 \%$ of floaters exclude Trypan blue. The number of live cells were counted for each treatment group at 24 hours and divided by the number of live cells in the untreated group at 24 hours and multiplied by 100 for percentage of cell survival. Cell counts were done for at least four replicates $(n=4)$ with each using five random fields for cell counts.

\section{Statistical analysis}

All experiments were performed a minimum of four times for at least four independent data points $(n=4)$. For any data point involving cell counting, a minimum of 200 cells were counted from at least five randomly chosen fields. The mean of the data points were taken and the standard error of the mean was calculated. Each data point was compared to the control values, or to a value from a comparison group to determine whether there was a significant difference. The data was analyzed by Student $t$-test and significance ( $\mathrm{p}$ value) calculated. $\mathrm{P}<0.001$ was determined to be significant.

\section{Results}

Here we report the effects of SSRIs on motor neuron health, as compared to untreated controls and ethanoltreated negative controls. The four panels of micrographs displayed in Figure 1A are from one exemplar experiment chosen from multiple experiments $(n=4)$. In Figure 1A 

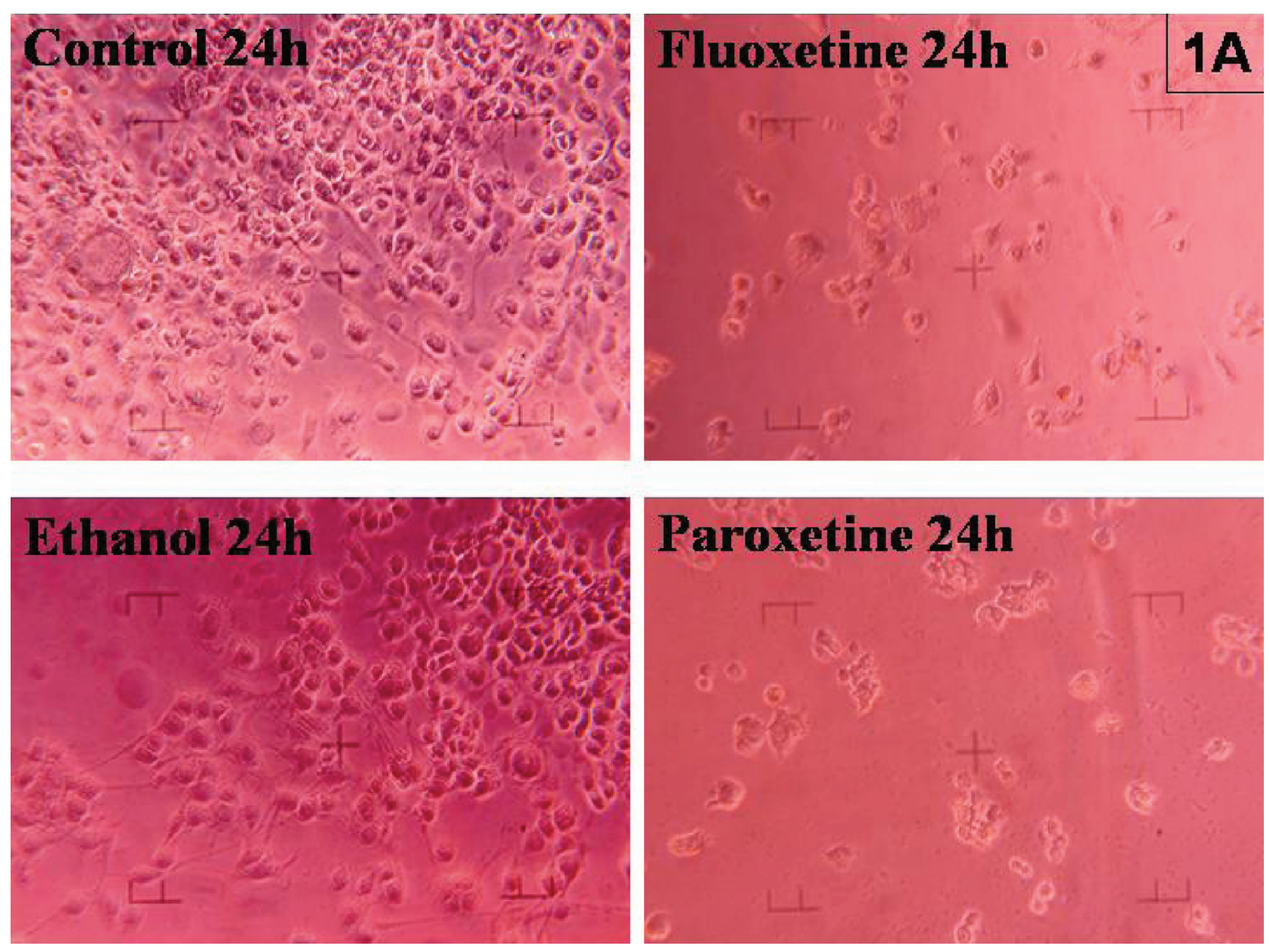

B

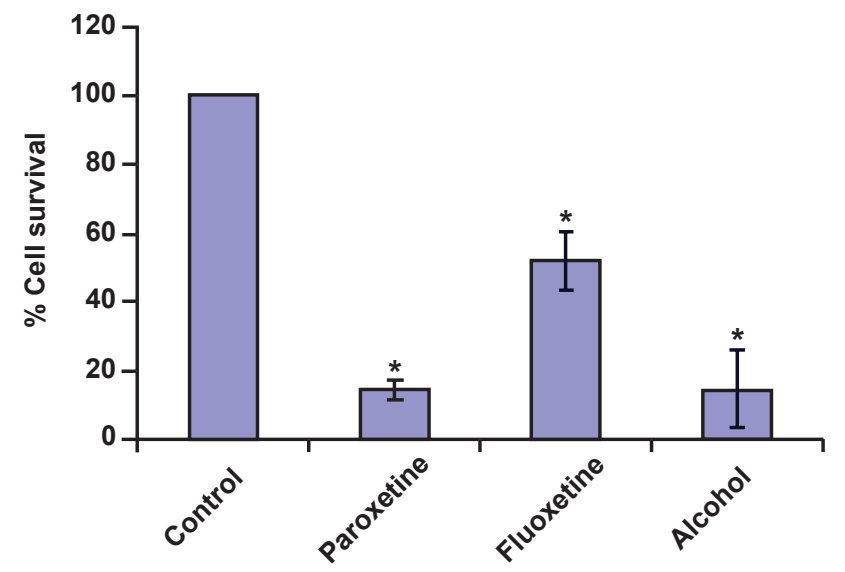

C

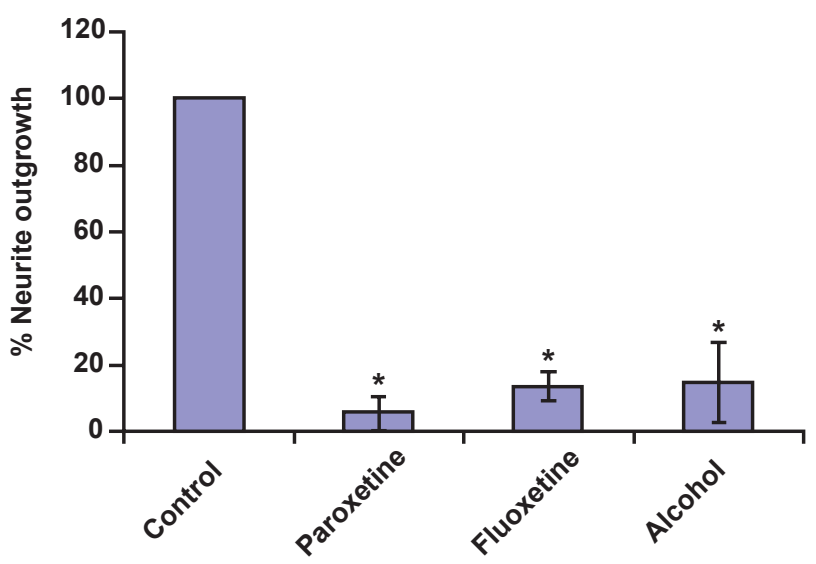

Figure I SSRI effects on motor neurons. A) Micrographs of treated motor neurons. Control $=$ cells untreated and incubated for 24 hours. Fluoxetine $=$ cells treated with $15 \mathrm{ng} / \mathrm{ml}$ fluoxetine and incubated for 24 hours. Paroxetine = cells treated with $3 \mathrm{l} \mathrm{ng} / \mathrm{ml}$ paroxetine and incubated for 24 hours. Ethanol = cells treated with $0.08 \%$ ethanol and incubated for 24 hours. Phase contrast micrographs taken at 100X mag. B) Percentage of cell survival after 24 hours. Cells were plated evenly and the number of cells 24 hours after the treatment was divided by the cells in that same well right before treatment to normalize for any unintended differences between each well. For all samples standard effort of the mean was calculated. All experimental groups were each compared to the UT control with an asterisk designating a significance of $p<0.00$ I. C) Percentage of neurite outgrowth after 24 hours. Cells were plated evenly and the number of cells bearing more than one neurite more than two cell bodies long 24 hours after the treatment was counted and divided by the total number of cells in that same well and multiplied by 100 for percentage of neurite outgrowth. For all samples standard effort of the mean was calculated. All experimental groups were each compared to the UT control with an asterisk designating a significance of $p<0.00$ I.

Abbreviation: SSRI, selective serotonin reuptake inhibitors. 

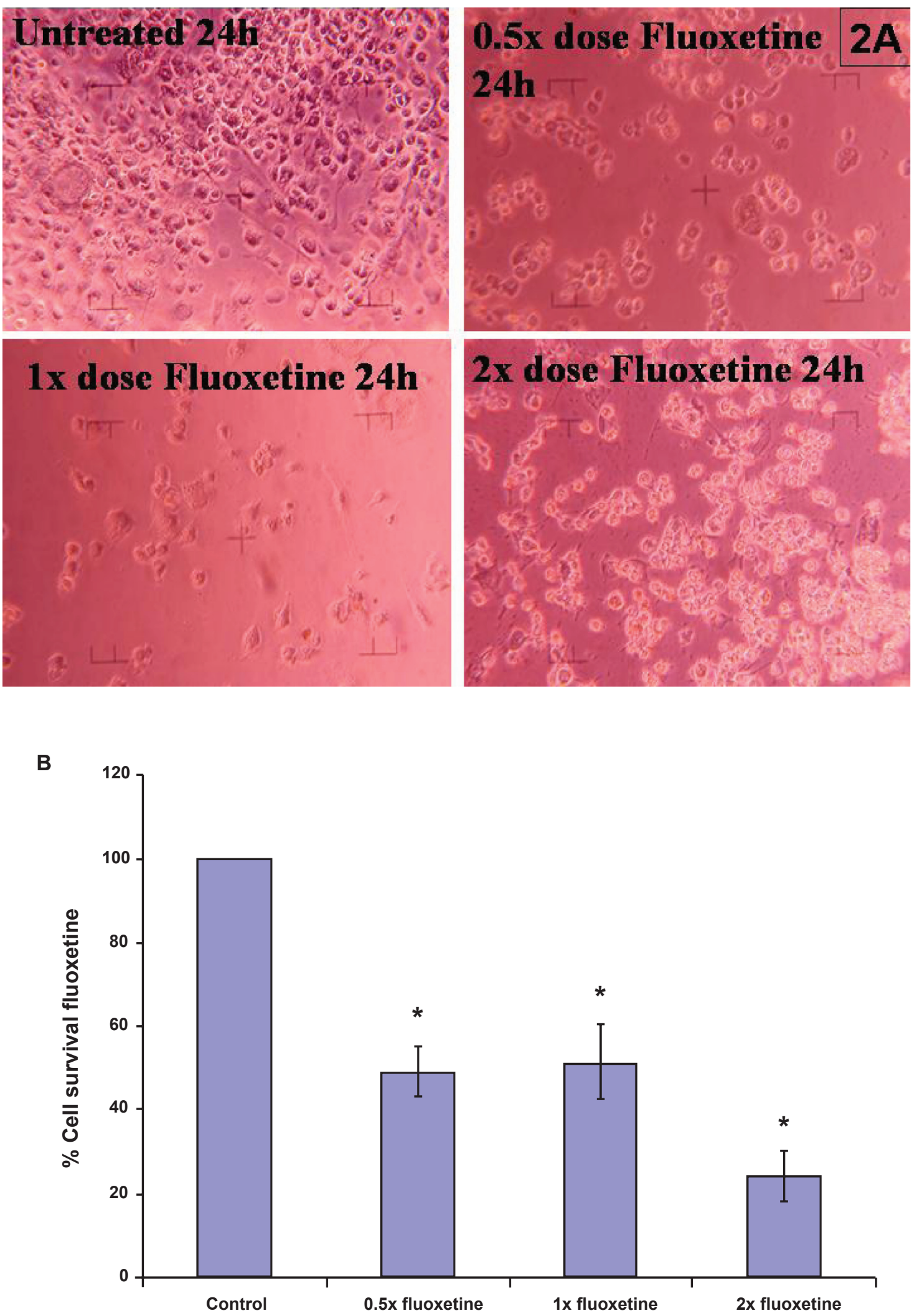

Figure 2 Dose response curve of fluoxetine. A) Micrographs of fluoxetine-treated motor neurons. Control = cells untreated and incubated for 24 hours. $0.5 x$ fluoxetine $=$ cells treated with $7 \mathrm{ng} / \mathrm{ml}$ fluoxetine and incubated for 24 hours. I fluoxetine = cells treated with $15 \mathrm{ng} / \mathrm{ml}$ fluoxetine and incubated for 24 hours. $2 \times$ fluoxetine $=$ cells treated with $30 \mathrm{ng} / \mathrm{ml}$ fluoxetine and incubated for 24 hours. Phase contrast micrographs taken at $100 \mathrm{X}$ mag. B) Percentage of cell survival after 24 hours. Cells were plated evenly and the number of cells 24 hours after the treatment was divided by the cells in that same well right before treatment to normalize for any unintended differences between each well. For all samples standard effort of the mean was calculated. All experimental groups were each compared to the UT control with an asterisk designating a significance of $p<0.001$. 

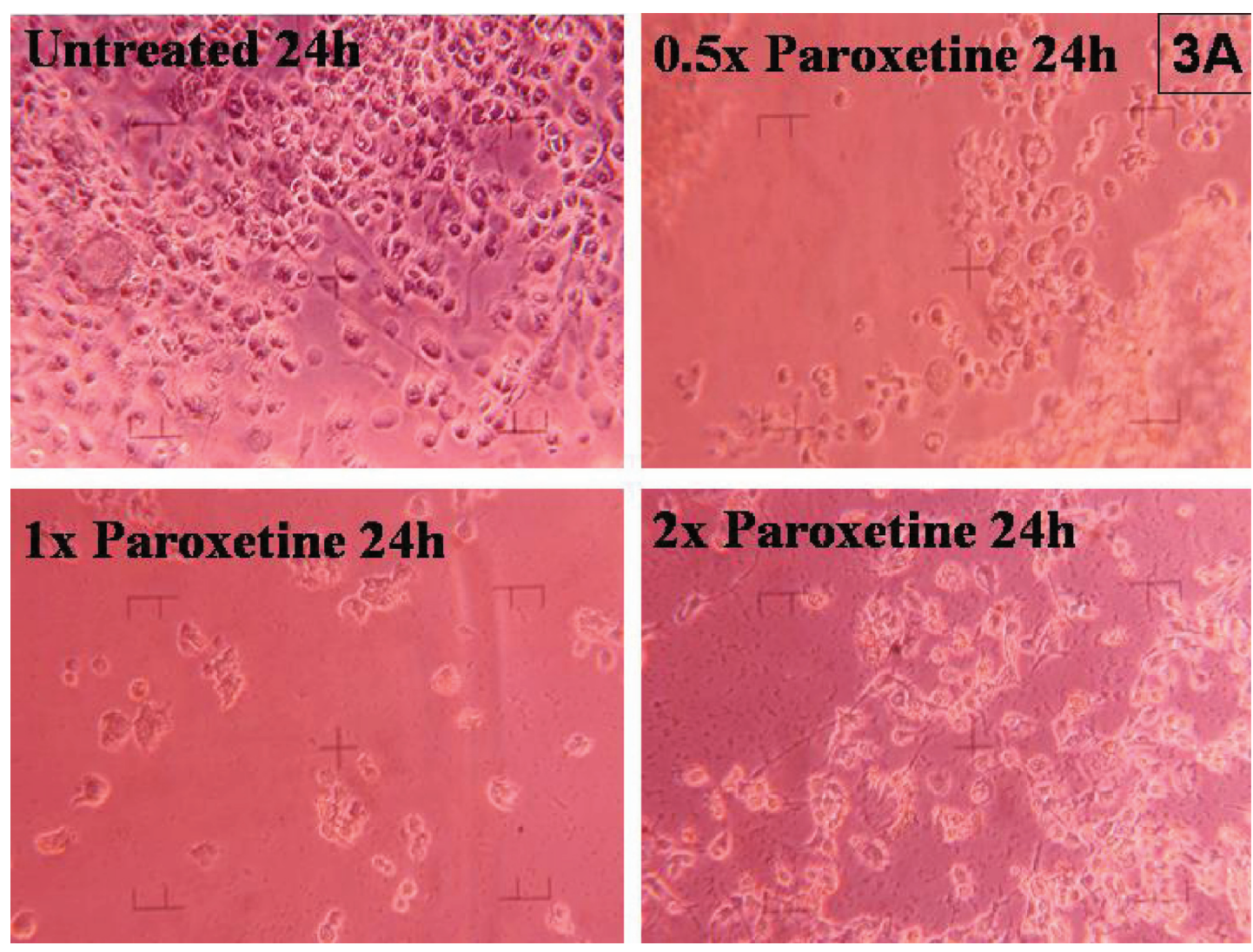

B

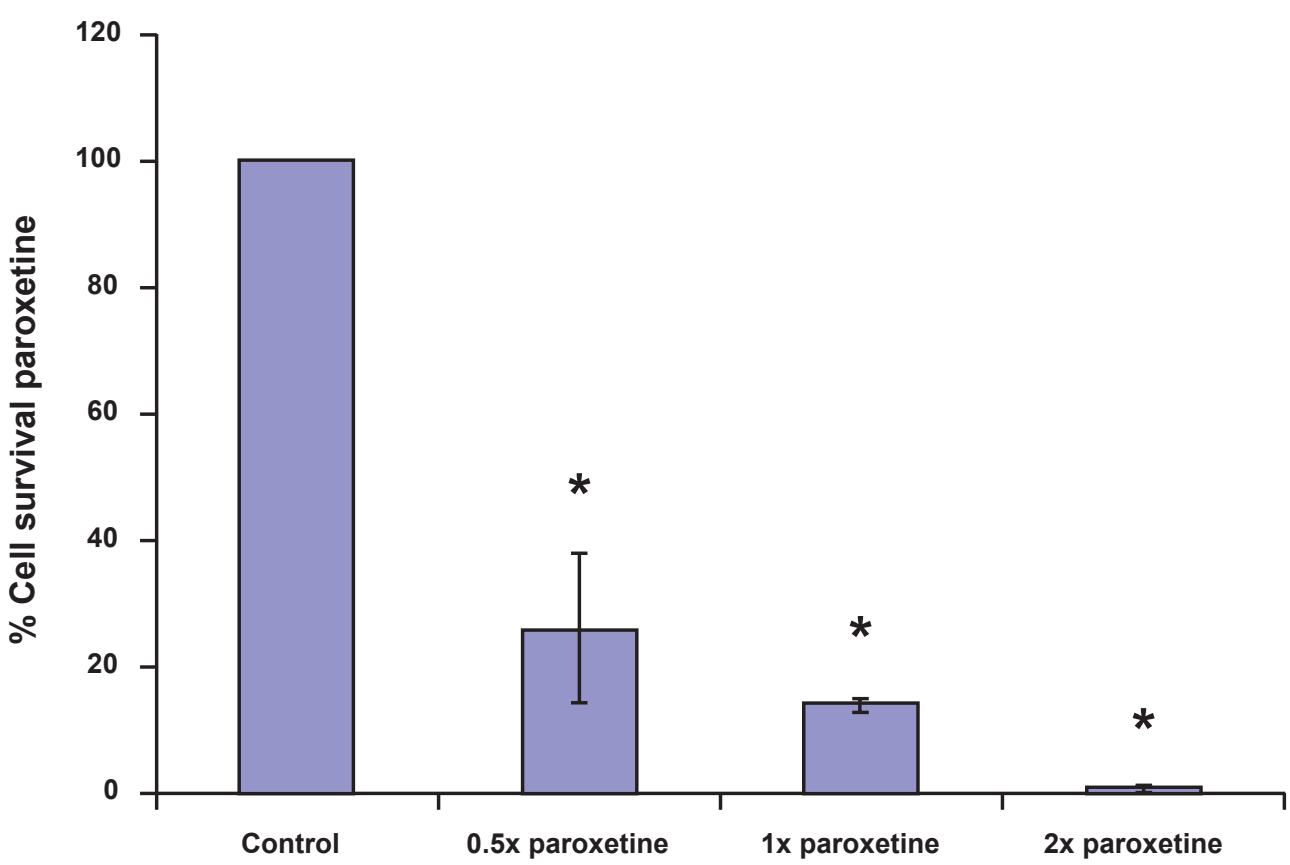

Figure 3 Dose response curve of paroxetine: $\mathbf{A}$ ) Micrographs of paroxetine-treated motor neurons. Control = cells untreated and incubated for 24 hours. $0.5 x$ paroxetine $=$ cells treated with $15.5 \mathrm{ng} / \mathrm{ml}$ paroxetine and incubated for 24 hours. Ix paroxetine = cells treated with $3 \mathrm{I} \mathrm{ng} / \mathrm{ml}$ fluoxetine and incubated for 24 hours. $2 \times$ paroxetine $=$ cells treated with $62 \mathrm{ng} / \mathrm{ml}$ paroxetine and incubated for 24 hours. Phase contrast micrographs taken at I00X mag. B) \% Cell survival after 24 hours. Cells were plated evenly and the number of cells 24 hours after the treatment was divided by the cells in that same well right before treatment to normalize for any unintended differences between each well. For all samples standard effort of the mean was calculated.All experimental groups were each compared to the UT control with an asterisk designating a significance of $\mathrm{p}<0.00 \mathrm{I}$. 
we see that the untreated cells look healthy with a high percentage of neurite-bearing cells while we see some toxicity in the ethanol-treated cells, while in the fluoxetineand paroxetine-treated cells there is profound toxicity as evidenced by the loss of cells and loss of neurite-bearing cells.

The data quantified in Figures $1 \mathrm{~B}$ and $\mathrm{C}$ shows the mean percentage of cell survival of four experiments with standard error of the mean, as well as the mean of percent of neurite-bearing cells for four experiments with the standard error of the mean calculated. In Figures $1 \mathrm{~B}$ and $\mathrm{C}$ we see that the untreated cells are healthy. The negative control cells treated with ethanol exhibit significant loss of cells with a percentage of cell survival of $14 \% \pm 1(n=4)$ and a percentage of neurite-bearing cells of $14 \% \pm 12(n=4)$. Cells treated with a single dose of paroxetine have cell survival of $14 \% \pm 4(n=4)$. The percentage of neuritebearing cells was $6 \% \pm 5(n=4)$. Cells that receive a single dose of fluoxetine have a cell survival of $52 \% \pm 9(n=4)$ with percentage of neurite-bearing cells of $13 \% \pm 4(n=4)$. Figure 1 clearly demonstrates toxicity of both SSRIs which is significant $(\mathrm{p}<0.001)$.

When we perform a dose-response curve of fluoxetine we see a dose-dependent decrease of cell survival in motor neurons. In Figure 2A we see a dose-dependent loss of cells and a complete loss of neurites at the $2 x$ flouxetine dose. When we quantify the percentage of cell survival we see that at half the therapeutic dose of fluoxetine there is $48 \% \pm 6(n=4)$, at the therapeutic dose fluoxetine there is $52 \% \pm 9(n=4)$ and at double the therapeutic dose there is $24 \% \pm 6(n=4)$. The decrease in percentage of cell survival are each significantly different from the control value $(\mathrm{p}<0.001)$. The decrease in percentage of cell survival seen when motor neurons are challenged with double the therapeutic dose is significantly different from the first two lesser fluoxetine doses $(\mathrm{p}<0.01)$.

When we perform a dose-response curve of paroxetine we see a dose-dependent decrease of cell survival in motor neurons. In Figure $3 \mathrm{~A}$ we see a dose-dependent loss of cells and a loss of neurites at the $2 x$ paroxetine dose. When we quantify the percentage of cell survival we see that at half the therapeutic dose of paroxetine there is $26 \% \pm 12(n=4)$, at the therapeutic dose paroxetine there is $14 \% \pm 11(\mathrm{n}=4)$ and at double the therapeutic dose there is $0.8 \% \pm 0.4(n=4)$. The decrease in percentage of cell survival are each significantly different from the control value $(\mathrm{p}<0.001)$. The decrease in percentage of cell survival seen when motor neurons are challenged with double the therapeutic dose is significantly different from the first two lesser paroxetine doses ( $\mathrm{p}<0.01)$.

When we compare cellular toxicity of fluoxetine with paroxetine it appears that paroxetine is profoundly more toxic than is fluoxetine (compare Figures $2 \mathrm{~B}$ and $3 \mathrm{~B}$ ), although both are toxic (Figure 1). In many slides paroxetine, killed $100 \%$ of neurons and even those still remaining on the slides were filled with blebs and disrupted cell membranes, none of which excluded Trypan blue (Figure 3 ).

\section{Discussion}

This experiment is an Ames Test utilizing CNS cells to assay for cellular toxicity. This is a study of possible neurotoxicity exhibited of the two most commonly presribed SSRI drugs. It is a straightforward experiment that tells us that the two SSRIs we assayed are profoundly toxic to motor neurons at the levels seen in serum of adolescent patients who are undergoing SSRI therapy. What is most interesting is that fluoxetine is very much less toxic than is paroxetine.

Although it is clear that treatment with SSRIs is toxic to motor neurons, we have to remember the blood-brain barrier and we have assumed that $100 \%$ of the serum concentration ends up in the CNS when we treated our cultures. What this study does do is alert us in the medical community that there appears to be SSRI-induced neurotoxicity and that a full exploration of the degree and mechanisms of this neurotoxicity needs to be assayed in whole animal models. And since it has been well established that the CNS of rodents do differ from humans in a variety of ways, most important of which is increased resistance to both cellular toxicity, oxidative stress, and carcinogenesis, the model that we may need to use is a primate.

\section{Disclosure}

The authors report no conflicts of interest in this work.

\section{References}

1. Eli Lilly and Company. Prozac (fluoxetine hydrochloride) prescribing information. Indianapolis, IN: Eli Lilly and Company; 2005.

2. GlaxoSmithKline. Paxil (paroxetine hydrochloride) prescribing information. London, UK: GlaxoSmithKline; 2008.

3. Xu Y, Sari Y, Zhou FC. Selective serotonin reuptake inhibitor disrupts organization of thalamocortical somatosensory barrels during development. Brain Res Dev Brain Res. 2004;150:151-161.

4. Bartholomä P, Erlandsson N, Kaufmann K, et al. Neuronal cell death induced by antidepressants: lack of correlation with Egr-1, NF-kappa $\mathrm{B}$ and extracellular signal-regulated protein kinase activation. Biochem Pharmacol. 2002;63:1507-1516.

5. Bishop A, Marquis JC, Cashman NR, Demple B. Adaptive resistance to nitric oxide in motor neurons. Free Radic Biol Med. 1999;26(7-8):978-986. 
6. Bishop A, Cashman NR. Induced adaptive resistance to oxidative stress in the CNS: Discussion of possible mechanisms and their therapeutic potential. Curr Drug Metabol. 2003;4:171-184.

7. Bishop A, Yet SF, Lee ME, Perrella MA, Demple B. Decreased resistance to nitric oxide in motor neurons of HO-1 null mice. Biochem Biophys Res Commun. 2004;325:3-9.
8. Cashman NR, Durham HD, Blusztajn JK, et al. Neuroblastoma $\times$ spinal cord (NSC) hybrid cell lines resemble developing motor neurons. Dev Dyn. 1992;194:209-221.

9. Durham HD, Dahrouge S, Cashman NR. Evaluation of the spinal cord neuron X neuroblastoma hybrid cell line NSC-34 as a model for neurotoxicity testing. Neurotoxicology. 1993;14:387-395.

\section{Publish your work in this journal}

The International Journal of General Medicine is an international, peer-reviewed open-access journal that focuses on general and internal medicine, pathogenesis, epidemiology, diagnosis, monitoring and treatment protocols. The journal is characterized by the rapid reporting of reviews, original research and clinical studies across all disease areas.
A key focus is the elucidation of disease processes and management protocols resulting in improved outcomes for the patient. The manuscript management system is completely online and includes a very quick and fair peer-review system. Visit http://www.dovepress.com/ testimonials.php to read real quotes from published authors.

Submit your manuscript here: http://www.dovepress.com/international-journal-of-general-medicine-journal 